Acta vet. scand. $1959,1,27-40$.

From the Department of Anatomy and Histology, Royal Veterinary College, Stockholm.

\title{
BONE MARROW CHANGES IN COWS IN CONNECTION WITH NORMAL PARTURITION, PARTURIENT PARESIS, AND RETAINED FOETAL MEMBRANES ${ }^{1}$ )
}

By

G. Winquist.

The blood changes in cows in connection with normal parturition (n.p.) are fairly well known. A thorough study was made by Moberg (10) who also reviewed the literature. The most impressing change seems to be a marked increase in the number of neutrophils starting already on the day before parturition and subsiding as soon as one day after parturition. The number of eosinophils is reported to increase slightly during the weeks before delivery and to drop considerably during labour.

The blood picture in parturient paresis (p.p.), a fairly common postparturient complication associated with hypocalcemia, has been studied by Garm (3) and Moberg (10). The changes seem to be of the same type as after n.p. but slightly more marked.

In the case of another common post-parturient complication, viz. retained foetal membranes (r.pl.), the blood picture has been studied by Moore (13) and later by Moberg (11). The main change is a marked neutropenia.

The bone marrow picture which is of prime importance for the understanding of the blood changes in these conditions has not been described but in a preliminary report by the present author (17) of the bone marrow changes at n.p. and r.pl. This paper is to report more fully of the bone marrow picture in all three conditions.

1) This investigation was aided by a grant from "Statens Medicinska Forskningsråd”, Uppsala, Sweden. 
Material: The n.p. material consists of 44 sternal punctures in 18 cows aged $3-14$ years. Ten of the punctures were performed 19-34 days before n.p., ten $1-9$ days before n.p., five on the day of n.p., twelve $1-3$ days after n.p., and seven $4-8$ days after n.p. In 13 of the cows 19 punctures altogether had been made $1-34$ days before n.p. and 16 punctures $1-6$ days after n.p. so that the changes within individual cows before and after n.p. could be analysed statistically.

The p.p. material consists of 11 sternal marrow samples obtained $1-2$ days after delivery from 11 cows aged $6-14$ years. The r.pl. material consists of 13 sternal aspirates obtained $1-3$ days after delivery from 11 cows aged 4-11 years, and one punctate taken before delivery from one of these cows. There were further four complicated and mixed cases which will be mentioned below.

All marrow samples were taken during the period November - May in the years 1955-1957. All animals belonged to the SRB breed (Swedish Red and White Breed) and most of them were high-producing animals fed on a diet rich in protein.

\section{METHODS}

Sternal puncture was performed on the standing animal with a $12 \mathrm{~cm}$. long puncture needle with a stylet, both of good steel. $1-2$ cc. were aspirated with a 10 cc. syringe. Thin cover slip smears were prepared immediately and stained with May-Grünwald-Giemsa stain on the same day. A differential count of 1000 cells was made from each case. As a rule, the rest of the aspirate was allowed to clot and then fixed in Zenkel-formol, embedded in paraffin wax, cut in sections 2-4 micra thick and stained with Lillie's (8) buffered azure-eosinate stain for histological study of the bone marrow fragments. Smears which had another cell distribution (because of too great admixture of blood) than the bone marrow fragments were discarded. Because of the varying content of blood and fat in the aspirates, sternal punctures from cattle cannot, unfortunately, be used for reliable total counts of nucleated cells.

The methods for statistical analysis were conventional as found e.g. in Fisher's (8) "Statistical Methods for Research Workers". The probability of obtaining a t-value at least as great as the calculated one for a given number of degrees of freedom (df) is 
found in Fisher's tables. If $p$ is greater than 0.05 the difference is said to be non-significant. If $p$ is between 0.01 and 0.05 the difference is said to be almost significant $\left(^{\star}\right)$. If $p$ is between 0.001 and 0.01 the difference is said to be significant $\left(^{\star \star}\right)$. If $p$ is 0.001 or less the difference is said to be highly significant $(\star \star \star)$.

If two or more marrow samples had been taken from the same cow during a certain period, the mean value was used in the calculations.

\section{RESULTS}

At n.p. the most impressing change occurred in the neutrophil series, starting already at the promyelocyte stage. As can be seen in Diagram 1, there was a slight increase in the percentage of all stages of neutrophils in the material $1-9$ days before n.p. as compared with that $19-34$ days before n.p. On the day of parturition there was a tendency to maturation inhibition or "shift to the left" in the neutrophil series. This was more pronounced $1-3$ days after parturition but subsided $4-8$ days after parturition, when the neutrophil stabs and segmented reached high values.

The statistical analysis was restricted to the 13 cows where marrow samples had been obtained $1-34$ days before and $1-6$ days after n.p. Table I gives the mean values $(\bar{x})$ for the difference in the percentage of each cell class before - after n.p. with tvalues and significance (df 12 ). Some cell classes have also been joined into larger groups.

There was thus a significant increase in the percentage of $n$. myelocytes and an almost significant increase of $n$. metamyelocytes after n.p. If these cells are treated as one group, the difference is highly significant. For all eosinophil cells together there was a significant decrease. The decrease in the erythroblasts has a high degree of significance. As could be expected, the relative increase in the neutrophil series and the decrease of erythroid cells led to a significant increase of the myeloid/erythroid ratio. There was also an almost significant increase in the percentage of plasma cells.

At p.p. 1-2 days after delivery as compared with n.p. $1-3$ days after delivery there was a somewhat higher percentage of promyelocytes and $n$. myelocytes and a lower percentage of $n$. stabs and segmented, as can be seen in Diagram 2. The statistical analysis (Table II) shows that the percentage of $n$. myelocytes 


\section{DIAGRAM 1 \\ Maturation curves of neutrophils in connection with n.p.}

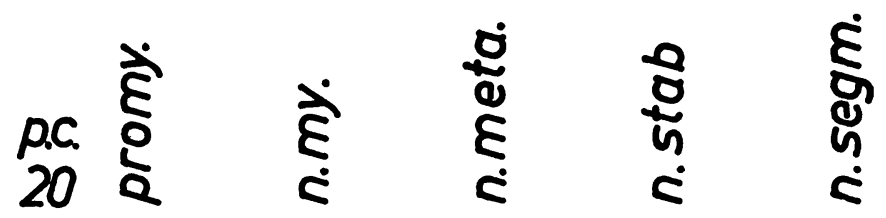

19

18

17

16

15

14

13

12

11

10

9

8

7

6

5

4

3

2

1

0

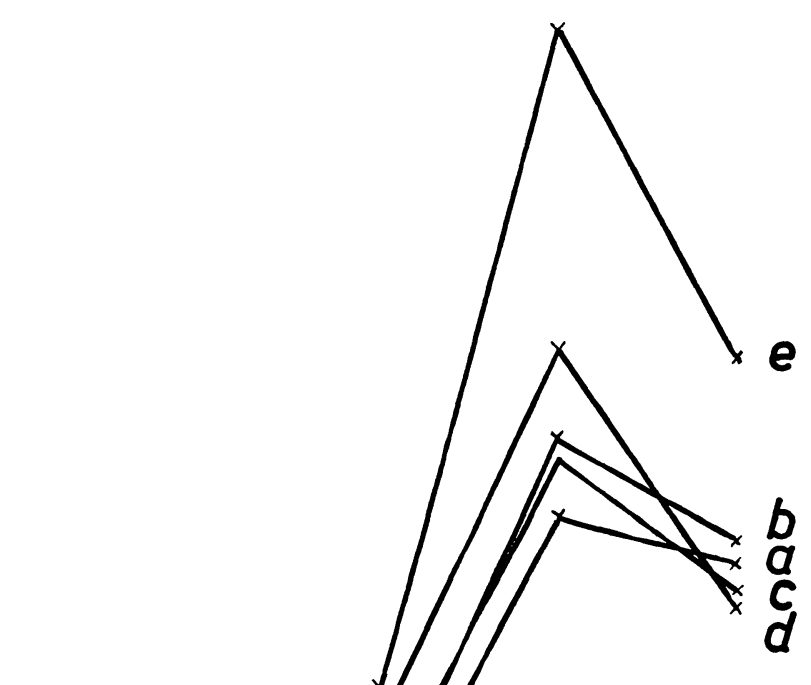

was almost significantly increased and that of monocytes almost significantly decreased but all other differences are non-significant. If promyelocytes and $n$. myelocytes are treated as one group the increase is almost significant. The difference in $\mathbf{n}$. stab 


\section{DIAGRAM 2 \\ Maturation curves of neutrophils at n.p.e p.p.e and r.pl.}

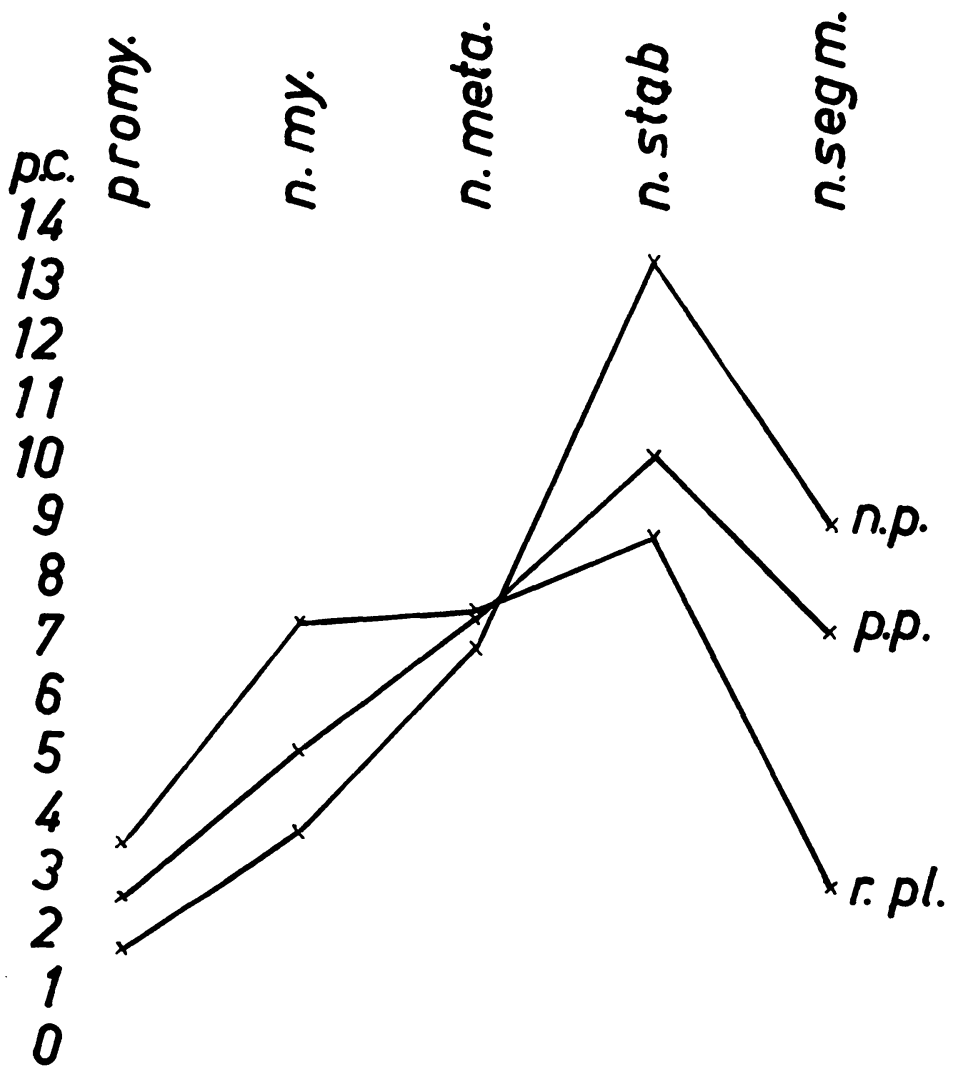

+ segm., all eosinophil stages, and all erythroid cells is still nonsignificant.

In the cases of r.pl. 1-3 days after delivery as compared with n.p. during the same period the increase in the percentage of promyelocytes and n. myelocytes and the decrease of $n$. stabs and segmented was much more pronounced than in the p.p. group, as can be seen in Diagram 2.

Thus the statistical analysis shows that the percentage of promyelocytes as well as that of $\mathbf{n}$. myelocytes is significantly higher in r.pl. If both cathegories are treated as one group the difference is even highly significant. The percentage of $n$. stabs is almost 

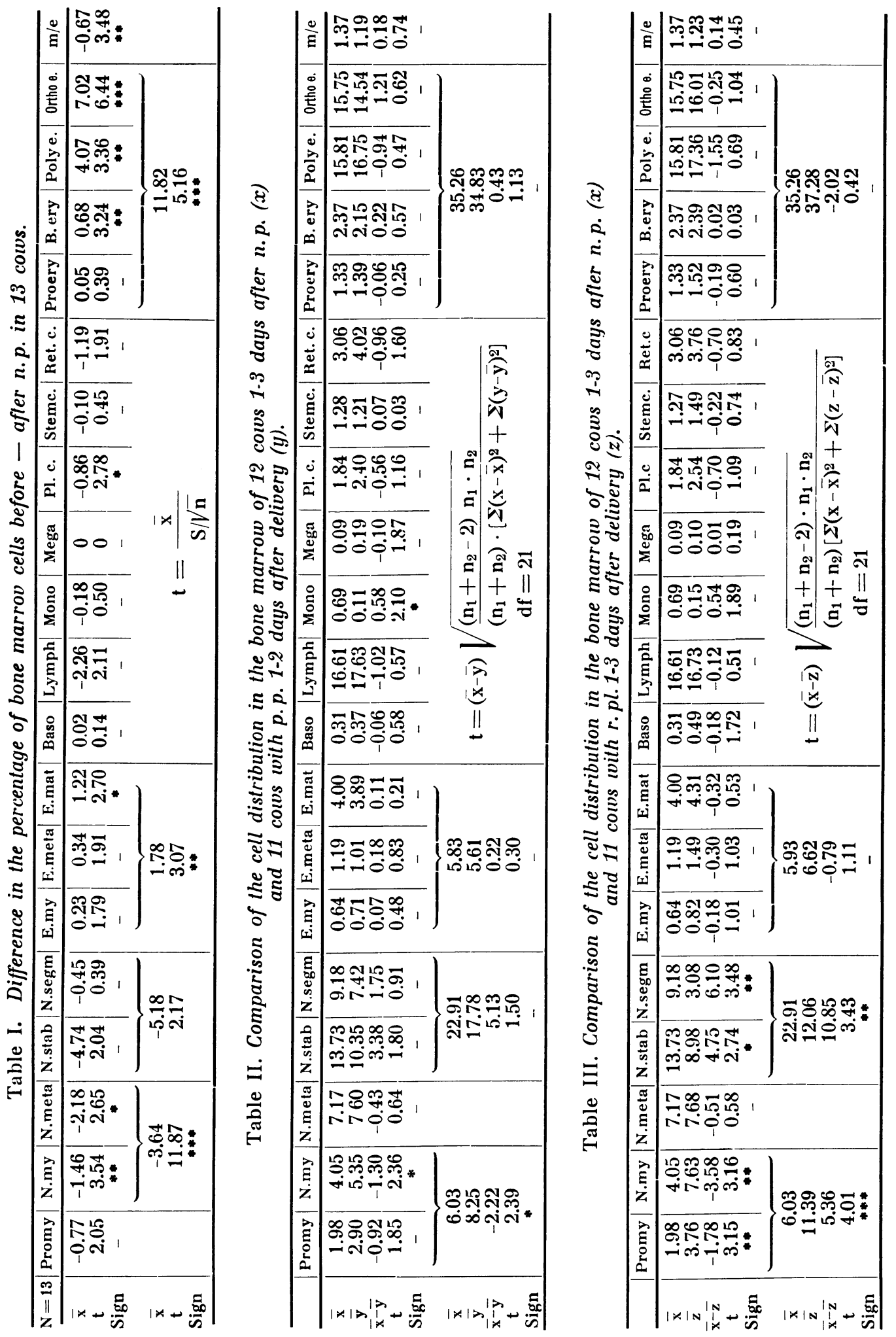
significantly lower and that of $\mathbf{n}$. segmented significantly lower. All other differences are non-significant.

The percentage of $n$. metamyelocytes remained strikingly constant in all three conditions. If we postulate that most of the promyelocytes were precursors of neutrophils, the maturation inhibition within the neutrophil series can be expressed as the

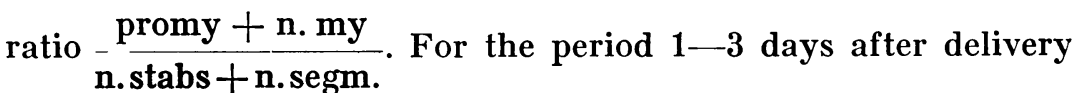
this ratio was 0.26 at n.p., 0.46 at p.p., and 0.94 at r.pl. The difference in the ratio between n.p. and p.p. is statistically almost significant ( $t=2.22$ with $21 \mathrm{df}$ ) and between n.p. and r.pl. highly significant $(t=4.00$ with $21 \mathrm{df}$ ).

In some cases the bone marrow was studied at fairly frequent intervals. This material is still far too small for statistical analysis, but some examples are given in Table IV and Table V.

Table IV. Changes in the percentage of some bone marrow elements in one case of r.pl.

\begin{tabular}{llrrrrrr}
\hline \multicolumn{1}{c}{ Time } & & Promy & N. my & N. meta & N. stab & N. segm & $\begin{array}{c}\text { All eosino- } \\
\text { phils }\end{array}$ \\
\hline 1 d. before part. & 2.0 & 7.1 & 7.3 & 8.8 & 3.3 & 5.1 \\
1 d. after & & 2.1 & 5.4 & 6.9 & 9.5 & 8.0 & 6.7 \\
2 d. " & d. & 1.6 & 5.6 & 5.8 & 9.3 & 7.3 & 7.2 \\
3 d. $"$ & $\#$ & 3.2 & 7.6 & 6.2 & 10.6 & 2.3 & 7.2 \\
\hline
\end{tabular}

Table V. Changes in the percentage of some bone marrow elements in a case of combined p.p. and r.pl.

\begin{tabular}{|c|c|c|c|c|c|c|c|}
\hline \multicolumn{2}{|l|}{ Time } & \multirow{2}{*}{$\begin{array}{c}\text { Promy } \\
0.7\end{array}$} & \multirow{2}{*}{$\frac{\text { N. my }}{1.2}$} & \multirow{2}{*}{$\frac{\text { N. meta }}{1.5}$} & \multirow{2}{*}{$\begin{array}{c}\text { N. stab } \\
9.0\end{array}$} & \multirow{2}{*}{$\frac{\text { N. segm }}{7.0}$} & \multirow{2}{*}{$\begin{array}{c}\begin{array}{c}\text { All eosino } \\
\text { phils }\end{array} \\
5.6\end{array}$} \\
\hline 34 d. before & part. & & & & & & \\
\hline $7 \mathrm{~d}$. & , & 2.5 & 3.3 & 4.5 & 8.6 & 6.2 & 3.6 \\
\hline $2 \mathrm{~d}$ & 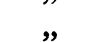 & 2.9 & 2.3 & 4.2 & 14.9 & 7.1 & 5.8 \\
\hline 2 d. after & $"$ & 4.7 & 5.9 & 11.2 & 13.1 & 1.6 & 6.9 \\
\hline
\end{tabular}

It is evident that in both cases there was some maturation inhibition in the neutrophil series already before delivery which became more pronounced after delivery. The percentage of eosinophils (mainly the mature forms) showed some increase after delivery. In this connection it should be mentioned that one case with extraordinary high eosinophil values in the myelogram has been excluded from the r.pl. material because of the fact that it had not been examined before parturation and the reason for the eosinophilia was not known. 
Two cases of twin-birth were excluded from the n.p. material because of the abnormal values. Both had normal myelograms before delivery, but after delivery there were drastic changes in the neutrophil series in spite of the fact that the deliveries were not complicated by p.p. or r.pl. A third case of twin-birth had r.pl. as well (see Table VI).

Table VI. Percentage of some bone marrow cells in three cases of twin-birth.

\begin{tabular}{lcrrrrc}
\hline Time & Promy & N. my & N. meta & N.stab & N. segm & $\begin{array}{c}\text { All eosino- } \\
\text { phils }\end{array}$ \\
\hline Just after part. & 4.0 & 7.1 & 14.5 & 10.4 & 5.0 & 3.6 \\
6 d. " " & 5.3 & 11.9 & 30.2 & 10.3 & 1.6 & 1.9 \\
r.pl. 3 d. after part. & 6.6 & 18.8 & 5.7 & 1.0 & 0 & 6.3 \\
\hline
\end{tabular}

To judge from these cases twin-birth is associated with a maturation inhibition in the neutrophil series which is at least as great as in the case of $r$. pl. The combination of twin-birth and r.pl. was accompanied by the most pronounced maturation inhibition met with in this investigation. The eosinophil values will be considered in the discussion.

Beside the changes in the cell composition described above, there were also qualitative changes in the neutrophil series, mainly in the r.pl. The characteristic findings were abnormal stainability of the granules ("toxic granulation"), irregular basophilia and vacuolization of the cytoplasm. The changes were met with only in the immature forms and did not occur in n. stabs or segmented. At closer examination it was found that these changes did not occur in the r.pl. cases only but in all cases with a strong maturation inhibition, e.g. the uncomplicated twin-births.

\section{DISCUSSION}

When the absolute numbers of bone marrow cells are not known, the conclusions based on the myelograms must be drawn with some caution. Sections of bone marrow fragments offer an opportunity, however, of determining whether the marrow is hyperplastic or hypoplastic. The estimation of the percentage of mitotically dividing cells in each cell class is another way to find out whether a relative decrease in a certain cathegory of cells is a real one or only the result of a strong increase of another cathegory or vice versa. 


\section{Normal parturition.}

Diagram 1 shows that the percentage of immature neutrophils had a tendency to increase already before delivery and reached the highest values $1-3$ days after calving. On the following 5 days the percentage of the most immature forms returned almost to pre-parturition levels while the percentage of the more mature forms were strongly elevated, indicating that the maturation inhibition had subsided and the newly formed cells had matured. The statistical analysis of the myelograms of 13 cows where the bone marrow of each animal was studied before as well as after parturition showed that the relative increase of $n$. myelocytes and metamyelocytes was essential. The highly significant decrease of erythroid cells might be mainly a relative one depending on an increase of other cells (Table I), since there was no decrease in the erythrocyte count or hemoglobin values after parturition (unpublished data). It should be mentioned, however, that the percentage of mitosis in the group proerytroblasts, basophilic erythroblasts, and polychromatic erythroblasts had decreased after parturition from 4.49 to 3.67 , indicating some depression of erythropoiesis. The sections of bone marrow fragments gave the impression that the bone marrow was more cellrich after parturition than before. The increase in the neutrophil series and mainly of its immature forms seems thus well established. In the case of twin-birth it seems to be still more pronounced (Table VI).

The mechanism for this increase is not fully understood. The neutrophilia and eosinopenia of the peripheral blood on the day of parturition have been interpreted by Moberg (11) and others as signs of increased pituitary-adrenocortical activity. The myelograms do not, however, support the view that this mechanism should be the dominating one. Thus Winquist (16) showed in goats that the injection of ACTH or cortisone caused an increase in the percentage of eosinophils in the marrow on the day after the injection but no regular changes in the neutrophil series. In guinea pigs Yoffey et al. (18) could demonstrate that the injection of Compound $\mathrm{E}$ (cortisone) gave a tendency to an absolute as well as relative increase in the number of erythroid cells and eosinophils and a depression of the myeloid/erythroid ratio; all contrary to the changes noted in the present investigation.

It is more likely that the increase in the neutrophil series in connection with parturition is caused by a nervous stimulation 
in the sense of $\operatorname{Hoff}$ (7) or produced in a neurohumoural way as suggested by Beer (4) and Rosenow (15). For reviews of the literature on this subject the reader is referred to Rohr (14) and Moeschlin (12).

\section{Parturient paresis.}

The bone marrow picture did not differ very much from that observed at normal parturition (Table II). Diagram 2 as well as the almost significantly higher percentage of the the $n$. myelocytes and the ratio $\frac{\text { promy }+n \cdot m y}{n . s t a b+n . s e g m}$ indicate that maturation inhibition was somewhat greater in p.p. than at n.p. It is quite likely that the neutrophil-stimulating principle active already at n.p. is still more active in p.p. Garm (3) found signs of an increased adrenocortical activity in p.p. and Moberg (11) interpreted the changes in the white blood picture in the same way. The bone marrow changes do not support this view (vide supra). The p.p. studied in this investigation was of the "classical" type with regard to the clinical course. The most consistent finding in this type is a marked hypocalcemia, Hallgren (4 and 5) and Hibbs (6), due to heavy loss of calcium at the onset a forced lactation. To the author's knowledge there are still no data on the effects of the hypocalcemia as such on the bone marrow. Evidently this problem requires further investigation.

\section{Retained placenta.}

The bone marrow changes in this condition were very striking (see Diagram 2 and Table III). Significant and highly significant changes occurred in the neutrophil series but in no other cell type or group of cells. The increase of the promyelocytes and $n$. myelocytes and the decrease of $n$. stabs and still more of $n$. segmented in cases of r. pl. as compared with n.p. during the same period seems thus very well established. It can also be expressed as a highly significantly higher ratio $\frac{\text { promy }+ \text { n. my } \cdot}{\text { n. stab. }+ \text { n. segm. }}$. The two cases represented in Table IV and Table $\mathrm{V}$ indicate that the tendency to maturation inhibition of the neutrophil series in cases with r.pl. was present already before parturition. This observation is of considerable interest for the understanding of the 
mechanism of the blood and bone marrow changes in r.pl. The neutropenia was explained by Moore (13) as due to the resorption of toxic substances during the decomposition of the placenta within the uterus and by Moberg (9) as due to an unusually great loss of neutrophils through the uterine wall in the case of r.pl. These interpretations do not fit well with the occurrence of bone marrow changes already before parturition, and Moberg (11) also noted that a neutropenia of the peripheral blood could be present already before parturition in cows developing r.pl. Obviously a losi; of mature neutrophils might well account for the low percentage of these cells in the bone marrow but it cannot explain the highly increased percentage of the most immature forms. It seems evident that in the case of r.pl. there is some principle involved, causing a strong maturation inhibition of the neutrophil series, in extreme cases approaching agranulocytosis. The nature of this principle is still unknown, but a material is now being collected of bone marrow samples before as well as after calving from cows with r.pl., and it is hoped that this material will make it possible to further elucidate this problem.

There was a tendency to higher values for the percentage of bone marrow eosinophils in cases with r.pl. as compared to normal parturition (Tables III, IV, V, and third case in Table VI). No definite conclusions can be drawn from these figures but the fact that the increase of the immature forms was more regular makes it tempting to consider the possibility that the presence of a retained placenta might stimulate eosinophil production to some degree.

The degenerative changes in the immature neutrophil cells in cases with r.pl. were at first thought to be signs of a toxic effect of the decaying placenta, but the fact that the same changes were present even in cases of normal parturition with high percentages of immature neutrophils makes it more likely that the changes had some connection with the degree of newformation itself.

\section{REFERENCES}

1. Beer, A. S.: Fol. haemat. 1942, 66, 222.

2. Fischer, M.: Statistical Methods for Research Workers. 10th Ed. Edinburgh/London 1948.

3. Garm, O.: Acta endocr. (Kbh) 1950, 5, 413.

4. Hallgren, W.: Zur Ätiologie und Pathogenese des Gebärkomas beim Rinde. Vet. med. Diss. Lund 1940. 
5. Hallgren, W.: Nord. Vet.-Med. 1955, 7, 433.

6. Hibbs, J. W.: J. Dairy Sc. 1950, 33, 758.

7. Hoff, F.: Fschr. Neurol. 1936, 8, 299.

8. Lillie, R. D.: Histopathologic Technic. Blakiston, Philadelphia/ Toronto 1948.

9. Moberg, R.: Proc. VII Nord. Veterinaermøte, Oslo 1954. A2, 46.

10. Moberg, R.: The White Blood Picture in Sexually Mature Female Cattle with Special Reference to Sexual Conditions. Vet. med. Diss. Uppsala 1955.

11. Moberg, R.: Proc. 3rd Int. Congr. Anim. Reprod. Cambridge 1956, 193.

12. Moeschlin, S.: Proc. 4th Int. Congr. Int. Soc. Hemat. Mar del Plata $1952,41$.

13. Moore, G. R.: J. Amer. vet. med. Ass. 1946, 109, 39.

14. Rohr, K.: Das menschliche Knochenmark. 2nd Ed. Thieme, Stuttgart 1949.

15. Rosenow, G.: Acta haemat. 1951, $5,1$.

16. Winquist, G.: Morphology of the Blood and the Hemopoietic Organs in Cattle under Normal and Some Experimental Conditions. Acta anat. 1954, Suppl. 21.

17. Winquist, G.: Proc. 3rd Int. Congr. Anim. Reprod. Cambridge 1956, 61.

18. Yoffey, J. M., Ancill, R. J., Holt, J. A. G., Owen-Smith, B., and Herdan, G.: J. Anat. 1954, 88, Part II: 115.

\section{SUMMARY}

The changes in the sternal bone marrow in connection with normal parturition were studied in 18 cows 13 of which were punctured before as well as after parturition. The bone marrow of cows with parturient paresis 1-2 days after delivery and retained foetal membranes 1-3 days after delivery was studied in 11 animals of each group and compared with that of 12 cows with normal parturition 1-3 days after delivery. At normal parturition there was an increase of all neutrophil stages which was highly significant regarding the most immature cells. The changes at various periods before and after parturition are shown in Diagram 1. There was also a statistically significant decrease in the percentage of eosinophils and a highly significant decrease in the percentage of erythroid cells.

In cases of parturient paresis the bone marrow picture did not differ very much from that observed at normal parturition, but the percentage of $n$. myelocytes was almost significantly higher.

In cases with retained foetal membranes there was a highly significant maturation inhibition within the neutrophil series with a very low percentage of mature neutrophils. Degenerative changes were met with in the immature neutrophils in all cases with a strongly increased percentage of immature neutrophils.

The findings are discussed and put in relation to reports of the blood picture in the same conditions and to experimental work on the bone marrow. 


\section{ZUSAMMENFASSUNG}

Das Knochenmarksbild der Kuh bei Normalpartus, Paresis puerperalis und zurückgebliebener Nachgeburt.

Wie bereits früher bekannt, ändert sich das weisse Blutbild im Zusammenhang mit dem Partus; die Neutrophilen nehmen nämlich bei normalen Partus (n.p.) und bei Paresis puerperalis (p.p.) an Anzahl zu, während beim Zurückbleiben der Nachgeburt (r.pl.) eine markierte Neutropenie auftritt.

Bei diesen verschiedenen Zuständen wurde deshalb das Knochenmark untersucht, um Voraussetzungen für ein besseres Verständnis der Variationen im Blutbilde zu schaffen. In der vorliegenden Arbeit wurde das Knockenmarksbild bei n.p. in Sternalpunktaten von 18 Kühen untersucht, von denen 13 sowohl vor als auch nach dem Partus punktiert wurden. Bei 11 Kühen mit p.p. wurden Sternalpunktate 1-2 Tage nach dem Partus erhalten, und 11 Tiere mit r.pl. wurden 1-3 Tage nach der Geburt punktiert. Das Knochenmarksbild bei p.p. und r.pl. wurde mit demjenigen bei 12 Tieren mit n.p. 1-3 Tage nach der Geburt verglichen.

Bei Normalpartus fand sich eine Zunahme im Prozentgehalt aller Stadien von Neutrophilen, die betreffs der am meisten unreifen Stadien statistisch stark signifikant war. Das Diagramm 1 zeigt, wie dieser Prozentgehalt zu verschiedenen Zeitpunkten vor und nach n.p. variiert. Die Eosinophilen wiesen eine signifikante prozentuale Verminderung und die Vorstadien der roten Blutkörperchen eine stark signifikante prozentuale Abnahme auf.

Bei Parese lagen im grossen ganzen dieselben Veränderungen im Knochenmark vor wie bei n.p., aber die prozentuale Zunahme der früheren Stadien war grösser, wie aus dem Diagramm 2 hervorgeht.

Bei zurückgebliebener Nachgeburt fand sich eine sehr markierte Reifungshemmung in der neutrophilen Reihe mit einer starken prozentualen Steigerung unreifer Formen, aber drastischer Abnahme der reifen Neutrophilen. Degenerative Veränderungen wurden in den unreifen Neutrophilen in allen Fällen wahrgenommen, in welchen dieselben eine starke prozentuale Zunahme aufwiesen.

Die gewonnenen Resultate werden mit Rücksicht auf das Blutbild bei denselben Zuständen und bei gewissen experimentellen Knochenmarksuntersuchungen diskutiert.

\section{SAMMANFATTNING}

Benmärgsbilden hos kor vid normalförlossning, pares och kvarbliven efterbörd.

Det är tidigare känt, att den vita blodbilden förändras i samband med partus; neutrofilerna öka sålunda i antal vid normalpartus (n.p.) och vid paresis puerperalis (p.p.), men vid kvarbliven efterbörd (r.pl.) uppträder en markerad neutropeni.

En undersökning av benmärgen vid dessa olika tillstånd har därför företagits för att skapa förutsättningar för en bättre förståelse av variationerna i blodbilden. I föreliggande arbete har benmärgsbilden 
vid n.p. undersökts i sternalpunktat från 18 kor, av vilka 13 punkterats både före och efter partus. På 11 kor med p.p. ha sternalpunktat erhållits 1-2 dagar efter partus, och 11 djur med r.pl. ha punkterats $1-3$ dagar efter förlossningen. Benmärgsbilden vid p.p. och r.pl. har jämförts med densamma hos 12 djur med n.p. 1-3 dagar efter förlossningen.

Vid normalpartus förelåg en ökning i procenthalten av alla stadier av neutrofiler, som var statistiskt starkt signifikant beträffande de mest omogna stadierna. Hur denna procenthalt varierar vid olika tidpunkt före och efter n.p. återges i diagram 1. Eosinofilerna visade en signifikant och förstadierna till röda blodkroppar en stark signifikant procentuell minskning.

Vid pares förelåg $i$ stort sett samma förändringar i benmärgen som vid n.p., men den procentuella ökningen av de tidigare stadierna var större, som framgår av diagram 2.

Vid kvarbliven efterbörd förelåg en mycket markerad mognadshämning $i$ den neutrofila serien med en stark procentuell ökning av omogna former men drastisk minskning av de mogna neutrofilerna. Degenerativa förändringar iakttogos i de omogna neutrofilerna i alla fall, där de visade en stark procentuell ökning.

De vunna resultaten diskuteras med hänsyn till blodbilden vid samma tillstånd och vissa experimentella benmärgsundersökningar.

(Received May 13. 1958). 